\title{
Total phenolics and flavonoids content, antioxidant activity and GC/MS analyses of Euphorbia grandialata
}

\author{
Mona Ismail ${ }^{\mathrm{a}}$, Asmaa I. Owis ${ }^{\mathrm{a}}$, Mona Hetta ${ }^{\mathrm{b}}$, Rabab Mohammed ${ }^{\mathrm{a} *}$ \\ ${ }^{a}$ Pharmacognosy Department, Faculty of Pharmacy, Beni-Suef University, Beni-Suef, 62111, Egypt. \\ ${ }^{\mathrm{b}}$ Pharmacognosy Department, Faculty of Pharmacy, Fayoum University, 63514, Egypt.
}

\begin{tabular}{|c|c|}
\hline ARTICLE INFO & ABSTRACT \\
\hline Article history: & Objective: This study has been designed to study phenolic and flavonoid contents quantitatively; screen \\
\hline Received on: 24/02/2017 & antioxidant activity and investigate unsaponifiable and saponifiable matters of Euphorbia grandialata R. aerial \\
\hline Accepted on: 13/04/2017 & parts. \\
\hline Available online: $30 / 06 / 2017$ & Methods: The phenolics and flavonoids content were assayed by Folin-Ciocalteu reagent and aluminium \\
\hline \multirow{7}{*}{$\begin{array}{l}\text { Key words: } \\
\text { Euphorbiaceae, phenolics, } \\
\text { DPPH, GC/MS. }\end{array}$} & $\begin{array}{l}\text { chloride reagent respectively, while the anti-oxidant activity was done by } 2,2 \text {-diphenyl-1-picrylhydrazyl } \\
\text { (DPPH).GC/MS analysis was used to analyze unsaponifiable and saponifiable matters. }\end{array}$ \\
\hline & Results: Total phenolics result was calculated as $(17.61 \pm 1.2 \mu \mathrm{g}$ gallic acid $/ \mathrm{g})$, total flavonoids as $(4.495 \pm 0.39$ \\
\hline & $\mu \mathrm{g}$ rutin $/ \mathrm{g})$ and anti-oxidants activity as (140.6 \% $\mu \mathrm{g}$ ascorbic acid/g). The identified compounds in \\
\hline & unsaponifiable matter were hydrocarbons $(51.1 \%)$, steroids and triterpenes $(35.92 \%)$. The saponifiable matter \\
\hline & showed fourteen components from which six were identified as methyl esters of saturated fatty acids ( $46.26 \%)$ \\
\hline & and eight as methyl esters of unsaturated fatty acids $(53.74 \%)$ \\
\hline & $\begin{array}{l}\text { Conclusion: Euphorbia grandialata could be considered as a valuable source of natural antioxidants. This is the } \\
\text { first report for phenolics and flavonoids content, antioxidant activity and GC/MS analysis of this plant. }\end{array}$ \\
\hline
\end{tabular}

\section{INTRODUCTION}

Euphorbiaceae, called the spurge family, is considered as a large family of flowering plants comprising around 300 genera with 7,500 species (Rahman, 2013). The medicinal uses of Euphorbia is due to their carminative (Bondarenko et al., 1972), diuretic (Liu et al., 2002), anti-leukemic (Kupchan and Uchida,1976), anti-inflammatory, analgesic (Singh et al.,1984; Heirmann, 1994), anti-asthmatic (Shelke et al., 2014), antioxidant (Sharma and Dey, 2007) and antimicrobial (Hussain et al., 2014) activities. The genus Euphorbia is rich in phenolic compounds such as scopoletin, scoparone, isoscopoletin, gallic acid (Wu et al., 2012), esculetin and phenylpropanoid-2hydroxydihydrocinnamic acid (Nazemiyeh et al., 2010) and flavonoids such as quercetin, quercitrin, quercitol, kaempferol, luteolin (Wu et al., 2012), kaempferol-3-glucoside, kaempferol

*Corresponding Author

Email: rmwork06@yahoo.com -3-galactoroside (Awaad et al., 2013), quercetin-3-glucoside, quercetin-3-glucuronide, quercetin-3-rhamnoside (Saleh, 1985), rutin and 5'-methoxy-8-methyl-6-prenyl-5,7-dihydroxy-3',4'methylenedioxy-flavone (Kumar and Intekhab, 2013).Euphorbia grandialata R. commonly known as "Candelabra tree", "Spurge", "Milkweed" or "Penge Euphorbia", is widely distributed in South Africa, rarely cultivated in Egypt.

It prefers well-drained soil, during the active growing season from March to September and the flowering stage during Summer (Dyer, 1937). Free radicals, which are produced by the chemical reaction of organic compounds, could damage the body's tissues and cells, leading to human aging and causing a variety of diseases. Therefore, it is important to find the antioxidants for scavenging these free radicals. Generally, two methods have been developed for the assessment of antioxidative activities including in vitro and in vivo screening. 1,1-Diphenyl-2- pierylhydrazyl (DPPH) method is one of the universal in vitro tools in which DPPH radical, a very stable nitrogen-centered radical, can be used to determine the free radical scavenging ability, which is 
related to their antioxidative activities. This method depends on spectrophotometric measurement of changes in concentration of $\mathrm{DPPH}^{\circ}$ which results from the reaction of the free radicals with an antioxidant (Meng et al., 2016).

All the reported studies about Euphorbias were related to polar constituents and nothing concerned their fixed oil, although fatty acids were known to have anticancer, antimutagenic and antimicrobial activities (Al Ashaal et al., 2010).Therefore, it was interesting to quantitatively study phenolic and flavonoid contents; screen the antioxidant activity and find its correlation with the phenolics and flavonoids content; in addition to the investigation of unsaponifiable and saponifiable matters of E. grandialata aerial parts growing in Egypt.

\section{MATERIALS AND METHODS}

General

UV-visible spectrophotometer (Shimadzu UV-1601 PC) was used. Analysis using GC/MS was carried out using a Thermo Scientific, Trace GC Ultra / ISQ Single Quadrupole MS and an electron ionization system with energy of $70 \mathrm{eV}$ for the ionization process. For GC of unsaponifiable matter, capillary column $(30 \mathrm{~m}$ $\mathrm{x} 0.25 \mathrm{~mm}$ ) packed with TG-5MS fused silica was used. The temperature of the oven was programmed at an initial temperature $50{ }^{\circ} \mathrm{C}$ (hold $2 \mathrm{~min}$.) to $150{ }^{\circ} \mathrm{C}$ at an increasing rate of $7{ }^{\circ} \mathrm{C} / \mathrm{min}$. then to $270^{\circ} \mathrm{C}$ at an increasing rate $5^{\circ} \mathrm{C} / \mathrm{min}$. (hold $2 \mathrm{~min}$.) then to $310{ }^{\circ} \mathrm{C}$ as a final temperature at an increasing rate of $3.5^{\circ} \mathrm{C} / \mathrm{min}$. (hold $10 \mathrm{~min}$.). The carrier gas was helium gas and used at a constant flow rate of $1 \mathrm{~mL} / \mathrm{min}$. For GC of saponifiable matter, capillary column $(30 \mathrm{~m} \quad \mathrm{x} \quad 0.25 \mathrm{~mm})$ packed with $70 \%$ cyanopropyl-polysilphenylenesiloxane was used. The temperature of the oven was programmed at an initial temperature $80{ }^{\circ} \mathrm{C}$ increased to $230{ }^{\circ} \mathrm{C}$ by the rate of $3{ }^{\circ} \mathrm{C} / \mathrm{min}$, then kept isothermal for $20 \mathrm{~min}$. The carrier gas was helium gas and used at a constant flow rate of $1.5 \mathrm{~mL} / \mathrm{min}$. 2, 2-diphenyl-1-picrylhydrazyl (DPPH), Folin-Ciocalteu reagents, gallic acid, rutin and ascorbic acid were purchased from E-Merck. Other chemicals used were of analytical grade.

\section{The Plant material}

Euphorbia grandialata R. was collected in October 2014 (from Shebin El-Qanater, Qalubiya, Egypt). It was identified by Dr. Abdelhalim Mohamed (Plant Taxonomy Department, Agricultural Research Institute, Egypt). A voucher specimen was placed at the Herbarium of Pharmacognosy Department, Faculty of Pharmacy, Beni-suef University under registration number BUPD-44. The fresh aerial parts were cut into small pieces and used in the subsequent experiments.

\section{Extraction}

The extraction of the fresh cut aerial parts of $E$. grandialata $(1 \mathrm{~g})$ was carried out at room temperature using $50 \mathrm{~mL}$ methanol $(80 \%)$ for $2 \mathrm{~h}$ on an orbital shaker adjusted at $200 \mathrm{rpm}$. The supernatant produced from mixture centrifugation for $20 \mathrm{~min}$. was transferred to a $100 \mathrm{~mL}$ volumetric flask. The procedure was repeated and respective supernatant was pooled. The final volume was adjusted to $100 \mathrm{~mL}$.

\section{Total phenolics content}

Using Folin-Ciocalteu reagent for determination of total phenolics content (Abu Bakar et al., 2009). The methanol extract $(300 \mu \mathrm{l})$ was added to $2.25 \mathrm{~mL}$ of Folin-Ciocalteu reagent and wait for $5 \mathrm{~min}$ at room temperature then add to the mixture2.25 $\mathrm{mL}$ of sodium carbonate $(60 \mathrm{~g} / \mathrm{L})$ solution and stand at room temperature for $90 \mathrm{~min}$ then measure the absorbance at $725 \mathrm{~nm}$. The standard curve was prepared using gallic acid for quantification purpose and the results were calculated as $\mu \mathrm{g}$ of gallic acid equivalent per $\mathrm{g}$ fresh weight.

\section{Total flavonoids content}

Using aluminium chloride method for determination of total flavonoids content (Abu Bakar et al., 2009). In a test tube, methanol extract $(0.5 \mathrm{ml})$ was added to $2.25 \mathrm{~mL}$ of distilled water then $0.15 \mathrm{~mL}$ of $5 \% \mathrm{NaNO}_{2}$ solution was added to the mixture. Wait for $6 \mathrm{~min}$. then add to the mixture $0.3 \mathrm{~mL}$ of $10 \%$ $\mathrm{AlCl}_{3} \cdot 6 \mathrm{H}_{2} \mathrm{O}$ solution. Stand for another 5 minutes then add $1.0 \mathrm{~mL}$ of $1 \mathrm{M} \mathrm{NaOH}$. Mix the mixture well using vortex. Immediately, the absorbance was measured spectrophotometrically at $510 \mathrm{~nm}$. The standard curve was prepared using rutin for quantification purpose and the results were calculated as $\mu \mathrm{g}$ of rutin equivalent per $g$ fresh weight.

\section{Antioxidant activity}

Using DPPH free radical model to determine the antioxidant activity (Abu Bakar et al., 2009). An aliquot of $300 \mu \mathrm{l}$ of samples were added to $3.0 \mathrm{~mL}$ of $500 \mu \mathrm{M}$ DPPH in absolute ethanol. Shake the mixture vigorously and wait for $30 \mathrm{~min}$ in the dark at room temperature. The absorbance was measured spectrophotometrically at $517 \mathrm{~nm}$. Ascorbic acid was used as a positive control. Using the following equation to calculate the free radical scavenging activity

Scavenging effect $(\%)=[1-($ absorbance of sample/absorbance of control)] x 100

\section{Statistical analysis}

All experiments were carried out three times and the result was represented as mean \pm standard errors. Microsoft Excel Windows 2013 was used to calculate the linear regression analysis and Pearson's correlation coefficient

\section{Preparation of the unsaponifiable matter (USM), the saponifiable (SM) and the fatty acid methyl esters (FAME) derivatives of SM}

The fresh cut aerial parts of E. grandialata $(7 \mathrm{~kg})$ were exhaustively extracted by cold maceration $(2000 \mathrm{ml}$, x4, each 48 h) with aqueous ethanol $(70 \%)$. The extract was evaporated under reduced pressure using a rotary evaporator. Distilled water (1L) was used to suspend the obtained residue $(200 \mathrm{~g})$ and fractionated 
successively with $n$-hexane $(500 \mathrm{~mL} \mathrm{x} \mathrm{4)} \mathrm{followed} \mathrm{by} \mathrm{evaporation}$ of hexane under reduced pressure. The $n$-hexane extract ( $10 \mathrm{~g}$ ) was saponified by subjecting it to heat under reflux with $100 \mathrm{~mL} 10 \%$ alcoholic potassium hydroxide together with $40 \mathrm{~mL}$ benzene for $24 \mathrm{~h}$ to make sure that hydrolysis had been completed. The saponified solution was concentrated under reduced pressure and suspended in $100 \mathrm{~mL}$ distilled water followed by extraction with diethyl ether $(10 \times 50 \mathrm{~mL})$ till exhaustion. Distilled water was used to wash the combined ether extract several times to remove alkalinity. Anhydrous sodium sulphate was used to dry ether extract, followed by evaporation till dryness. The solvent-free residue obtained representing the unsaponifiable matters (USM), was orange-yellow in color and amounted to $8 \mathrm{~g}$ calculated as $80 \%$ of the total lipoidal composition of the corresponding $n$-hexane extract. The dried residue was kept in a desiccator for GC/MS analysis (Vogel, 1975). Liberation of the free fatty acids (FA) from the aqueous alkaline solution left after separation of the unsaponifiable matter was done by acidification with dilute $\mathrm{HCl}$ $(10 \%)$. The FA was extracted with diethyl ether $(5 \times 50 \mathrm{~mL})$. Distilled water was used to wash the combined ether extract to remove acidity. Anhydrous sodium sulphate was used to dry ether extract, followed by evaporation till dryness. The oily residue obtained representing the saponifiable matters (SM), amounted to $2 \mathrm{~g}$ calculated as $20 \%$ of the total lipoidal composition of the corresponding $n$-hexane extract (Vogel, 1975). SM was subjected to methylation to afford fatty acid methyl esters (FAME) derivatives of SM (Vogel, 1975). Chemical investigation using GC/MS technique was conducted to identify components of USM and FAME. A tentative identification of both USM and FAME components was doneby comparison between their relative retention time and mass spectra with those of the NIST, WILLY library data of the GC/MS system. The quantification of all identified components was based on the integration of the area under the peak.

\section{RESULTS AND DISCUSSION}

\section{Total phenolics, flavonoids content and antioxidant activity}

Spectrophotometric determination of total phenolics content in E. grandialata alcoholic extract was done according to Folin-Ciocalteu method using gallic acid as the standard. Results showed that $17.61 \pm 1.2 \mu \mathrm{g}$ of gallic acid were equivalent to $1 \mathrm{~g}$ of fresh weight, and the results of total flavonoids content determination by aluminium chloride method was $4.495 \pm 0.39 \mu \mathrm{g}$ rutin were equivalent to $1 \mathrm{~g}$ fresh weight. Antioxidant assay of the methanol extract showed scavenging capacity to the free radical DPPH $140.6 \% \mu \mathrm{g}$ ascorbic acid/gin comparison to standard ascorbic acid as positive control.

Plants with high contents of secondary metabolites especially phenolics and flavonoids were known to have antioxidant efficacy because of their redox properties and chemical structures. Phenolic compounds are one of the most abundant phytochemicals in plants. They play important role since they safeguard against ultraviolet rays and ensure security against microbial attack and predators (Naczk,2006).The abilities of phenolic compounds for scavenging free radical are due to their hydroxyl groups (Soobrattee et al., 2005). It showed antioxidant efficacy by different strategies like donating hydrogen atoms to free radicals or through binding to transition metal ions resulting in more stable forms (Kumar and Sandhir, 2014). Accordingly, polyphenol showed some physiological activities such as the protection against neurodegenerative and cardiovascular diseases and cancer since they have a high antioxidant capacity (WoottonBeard and Moran,2011). Also, flavonoids showed in vitro and in vivo antioxidant activities which depends on the free $\mathrm{OH}$ groups, particularly 3-OH (Geetha et al., 2003; Shimoi et al., 1996).

DPPH assay has been used worldwide as a method to determine the free radical scavenging capacity of various plant extracts due to its simplicity and relatively short time compared to other methods (Majewska et al., 2011). E. grandialata alcoholic extract showed high antioxidant activity. According to previous studies (Pietta 2000; Michalak, 2006) this activity was thought to be due to the high content of phenolics and flavonoids in this plant. The high content of phenolics and flavonoids is the accountable for the antioxidant efficacy of the plant extract. Flavonoids are considered as the highly efficacious scavengers of majority of oxidizing molecules and free radicals involved in many diseases (Bravo, 1998). They have the ability to inhibit the formation of reactive oxygen, bind to trace elements implicated the production of the free radical and clean out reactive species (Agati et al., 2012). Crude extracts of plant materials rich in phenolics were known have antioxidative properties and health benefits, so far it could used in the food industry for (Baba and Malik 2015) This study has been conducted for other Euphorbia species as E. hirta (Asha et al., 2016), E. helioscopia (Maoulainine et al., 2012), E. echinus (Lahlou et al., 2014)and E. heterophylla (Abbasi et al., 2013), but this is the first report for antioxidant study of E. grandialata.

\section{Identification of SM and USM components using GC/MS technique}

The results of GC/MS analysis of the saponifiable matter of E. grandialata aerial parts (Fig.1 and Table 1) revealed the presence of 14 components from which six were identified as methyl esters of saturated fatty acids (46.26\%) and eight were identified as methyl esters unsaturated fatty acids (53.74\%). Methyl isohexadecanoate was the major saturated fatty acid $(33.13 \%)$ while 8,11 -octadecadienoic acid was the predominant unsaturated fatty acid $(25.70 \%)$ followed by 9,12,15Octadecatrienoic acid (14.45\%) then 9-Octadecenoic acid $(10.35 \%)$. On the other hand, 29 components were identified in USM (Fig.2 and Table 2). The identified compounds were hydrocarbons $(51.1 \%)$ from which 1-nonanolwas the major $(7.23 \%)$. In addition to sterols and triterpenes $(35.92 \%)$ from which lanosta-8, 24-dien-3-olwas the major sterol $(4.48 \%), \mathrm{A}^{\prime}-$ neogammacer-5-en-3-ol (14.35\%), and $\alpha$-amyrin (5.39\%) were the major triterpenes. It could be considered the first GC/MS analysis report of one species from genus Euphorbia. 
Table 1: GC/MS analysis of the saponifiable matters of the $n$-hexane extract of Euphorbia grandialata R.aerial parts.

\begin{tabular}{|c|c|c|c|c|c|}
\hline $\begin{array}{c}\text { Peak } \\
\text { no }\end{array}$ & Identified Components & $\mathbf{R}_{\mathbf{t}}$ & $\%$ Area & $\begin{array}{c}\text { Molecular } \\
\text { weight }\end{array}$ & $\begin{array}{c}\text { Molecular } \\
\text { formula }\end{array}$ \\
\hline 1 & Dodecanoic acid, methyl ester $\left(\mathrm{C}_{13}\right)$ & 13.22 & 2.23 & 214 & $\mathrm{C}_{13} \mathrm{H}_{26} \mathrm{O}_{2}$ \\
\hline 2 & Methyl tetradecanoate $\left(\mathrm{C}_{15}\right)$ & 18.59 & 4.65 & 242 & $\mathrm{C}_{15} \mathrm{H}_{30} \mathrm{O}_{2}$ \\
\hline 3 & Methyl 13-methyltetradecanoate $\left(\mathrm{C}_{16}\right)$ & 21.20 & 0.99 & 256 & $\mathrm{C}_{16} \mathrm{H}_{32} \mathrm{O}_{2}$ \\
\hline 4 & Ethyl 9-tetradecenoate $\left(\mathrm{C}_{16: 1}\right)$ & 21.56 & 0.52 & 254 & $\mathrm{C}_{16} \mathrm{H}_{30} \mathrm{O}_{2}$ \\
\hline 5 & Methyl isohexadecanoate $\left(\mathrm{C}_{17}\right)$ & 23.75 & 33.13* & 270 & $\mathrm{C}_{17} \mathrm{H}_{34} \mathrm{O}_{2}$ \\
\hline 6 & 9-Hexadecenoic acid, methyl ester $\left(\mathrm{C}_{17: 1}\right)$ & 24.32 & 0.33 & 268 & $\mathrm{C}_{17} \mathrm{H}_{32} \mathrm{O}_{2}$ \\
\hline 7 & 11-Hexadecenoic acid, methyl ester $\left(\mathrm{C}_{17: 1}\right)$ & 24.54 & 0.51 & 268 & $\mathrm{C}_{17} \mathrm{H}_{32} \mathrm{O}_{2}$ \\
\hline 8 & Heptadecanoic acid, methyl ester $\left(\mathrm{C}_{18}\right)$ & 26.12 & 1.51 & 284 & $\mathrm{C}_{18} \mathrm{H}_{36} \mathrm{O}_{2}$ \\
\hline 9 & Methyl stearate $\left(\mathrm{C}_{19}\right)$ & 28.45 & 3.75 & 298 & $\mathrm{C}_{19} \mathrm{H}_{38} \mathrm{O}_{2}$ \\
\hline 10 & 9-Octadecenoic acid, methyl ester $\left(\mathrm{C}_{19: 1}\right)$ & 29.06 & $10.35^{*}$ & 296 & $\mathrm{C}_{19} \mathrm{H}_{36} \mathrm{O}_{2}$ \\
\hline 11 & 12-Octadecenoic acid, methyl ester $\left(\mathrm{C}_{19: 1}\right)$ & 29.25 & 1.30 & 296 & $\mathrm{C}_{19} \mathrm{H}_{36} \mathrm{O}_{2}$ \\
\hline 12 & 8,11-Octadecadienoic acid, methyl ester $\left(\mathrm{C}_{19: 2}\right)$ & 30.38 & 25.70* & 294 & $\mathrm{C}_{19} \mathrm{H}_{34} \mathrm{O}_{2}$ \\
\hline 13 & $9,12,15$-Octadecatrienoic acid, methyl ester $\left(C_{19: 3}\right)$ & 31.96 & $14.45^{*}$ & 292 & $\mathrm{C}_{19} \mathrm{H}_{32} \mathrm{O}_{2}$ \\
\hline 14 & 11-Eicosenoic acid, methyl ester $\left(\mathrm{C}_{21: 1}\right)$ & 33.41 & 0.58 & 324 & $\mathrm{C}_{21} \mathrm{H}_{40} \mathrm{O}_{2}$ \\
\hline \multicolumn{2}{|c|}{ Total identified components } & & $100 \%$ & & \\
\hline \multicolumn{2}{|c|}{ Total identified saturated fatty acid } & & 46.26 & & \\
\hline \multicolumn{2}{|c|}{ Total identified unsaturated fatty acid } & & 53.74 & & \\
\hline
\end{tabular}

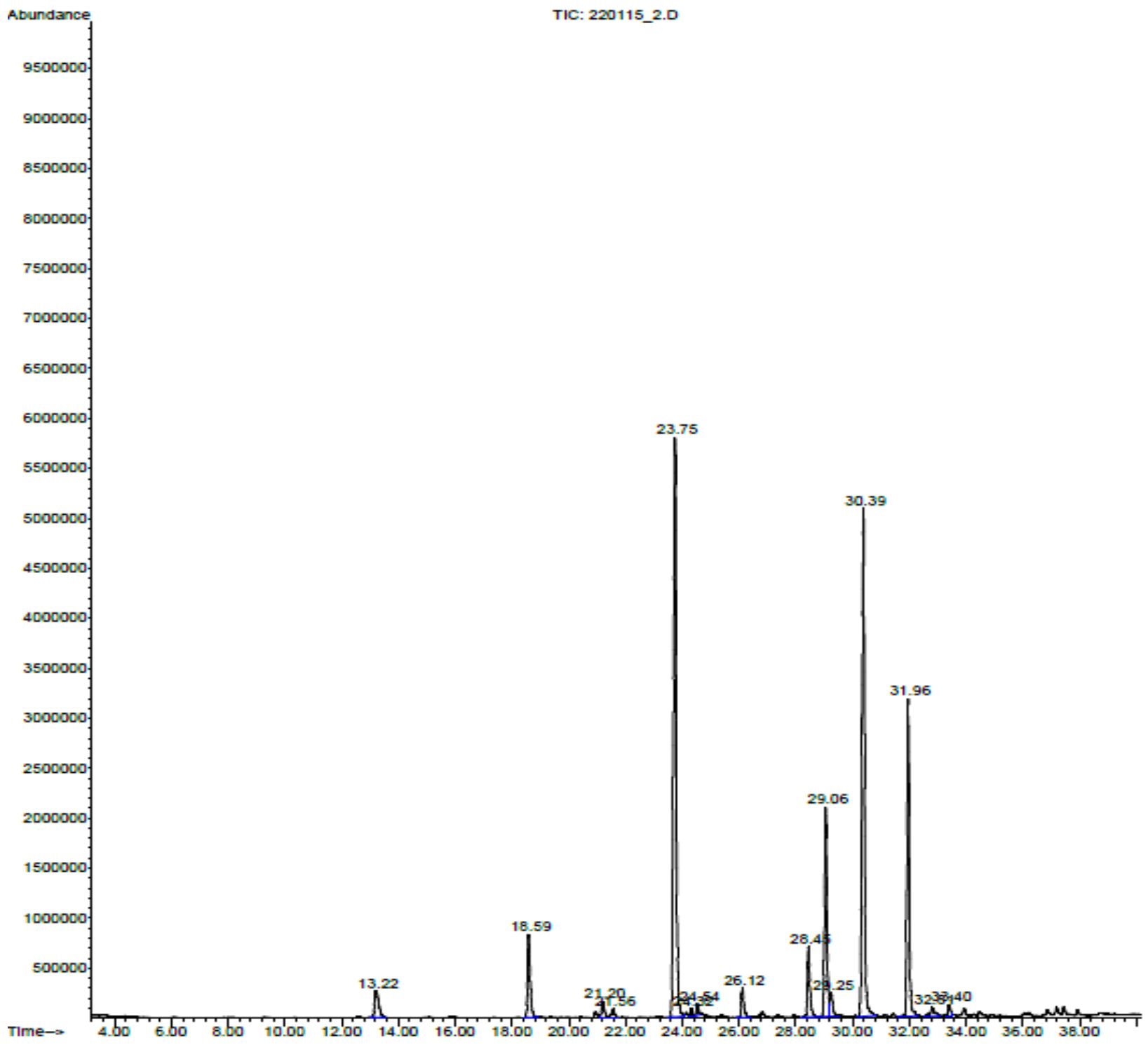

Fig. 1: GC/MS chromatogram of the saponifiable matters of Euphorbia grandialata R. aerial parts. 
Table 2: GC/MS analysis of the unsaponifiable matters of the $n$-hexane extract of Euphorbia grandialata R.aerial parts.

\begin{tabular}{|c|c|c|c|c|c|}
\hline $\begin{array}{c}\text { Peak } \\
\text { no }\end{array}$ & Identified components & $\mathbf{R}_{\mathbf{t}}$ & $\%$ Area & $\begin{array}{l}\text { Molecular } \\
\text { weight }\end{array}$ & $\begin{array}{l}\text { Molecular } \\
\text { formula }\end{array}$ \\
\hline 1 & 9-Borabicyclo[3.3.1]nonane-9-ol & 10.28 & 0.83 & 138 & $\mathrm{C}_{8} \mathrm{H}_{15} \mathrm{BO}$ \\
\hline 2 & 9-n-Dodecylperhydrophenanthrene & 11.49 & 0.96 & 360 & $\mathrm{C}_{26} \mathrm{H}_{48}$ \\
\hline 3 & Spiro[4.5]decane-6,10-dione & 11.84 & 0.81 & 166 & $\mathrm{C}_{10} \mathrm{H}_{14} \mathrm{O}_{2}$ \\
\hline 4 & Docosane & 12.94 & 1.25 & 310 & $\mathrm{C}_{22} \mathrm{H}_{46}$ \\
\hline 5 & 17-Pentatriacontene & 13.32 & 1.02 & 490 & $\mathrm{C}_{35} \mathrm{H}_{70}$ \\
\hline 6 & 2,6-Dimethylundecane & 13.52 & 4.66 & 184 & $\mathrm{C}_{13} \mathrm{H}_{28}$ \\
\hline 7 & Isocolchifoline & 17.49 & 3.45 & 415 & $\mathrm{C}_{22} \mathrm{H}_{25} \mathrm{NO}_{7}$ \\
\hline 8 & 3-Ethyl-5- (2-ethylbutyl)octadecane & 18.75 & 1.34 & 366 & $\mathrm{C}_{26} \mathrm{H}_{54}$ \\
\hline 9 & Tridecanol & 19.91 & 3.36 & 200 & $\mathrm{C}_{13} \mathrm{H}_{28} \mathrm{O}$ \\
\hline 10 & Methyl 5-hydroxy-5-methyl-5,6,7,8-tetrahydronaphthalene-1-carboxylate & 20.18 & 5.56 & 220 & $\mathrm{C}_{13} \mathrm{H}_{16} \mathrm{O}_{3}$ \\
\hline 11 & Curan-17-oicacid,19- (acetyloxy)-2,16-didehydro-20-hydroxy,methylester & 21.35 & 0.94 & 398 & $\mathrm{C}_{22} \mathrm{H}_{26} \mathrm{~N}_{2} \mathrm{O}_{5}$ \\
\hline 12 & 2,2,4,9,11,11-Hexamethyldodecane & 22.28 & 4.47 & 254 & $\mathrm{C}_{18} \mathrm{H}_{38}$ \\
\hline 13 & Heneicosane & 23.28 & 1.12 & 296 & $\mathrm{C}_{21} \mathrm{H}_{44}$ \\
\hline 14 & Nonacosane & 24.59 & 4.83 & 408 & $\mathrm{C}_{29} \mathrm{H}_{60}$ \\
\hline 15 & 1-Nonanol & 26.83 & $7.23 *$ & 144 & $\mathrm{C}_{9} \mathrm{H}_{20} \mathrm{O}$ \\
\hline 16 & Colchifoleine & 28.99 & 2.20 & 401 & $\mathrm{C}_{21} \mathrm{H}_{23} \mathrm{NO}_{7}$ \\
\hline 17 & Gibberellic acid & 32.93 & 1.30 & 346 & $\mathrm{C}_{19} \mathrm{H}_{22} \mathrm{O}_{6}$ \\
\hline 18 & Antirliine & 33.70 & 0.81 & 296 & $\mathrm{C}_{19} \mathrm{H}_{24} \mathrm{~N}_{2} \mathrm{O}$ \\
\hline 19 & Isooctylvinyl Ether & 34.76 & 1.65 & 156 & $\mathrm{C}_{10} \mathrm{H}_{20} \mathrm{O}$ \\
\hline 20 & $(3 \beta, 15 \alpha, 16 \alpha, 21 \beta, 22 \alpha)$-Olean-12-ene-3,15,16,21,22,28-hexol & 36.56 & 0.89 & 506 & $\mathrm{C}_{30} \mathrm{H}_{50} \mathrm{O}_{6}$ \\
\hline 21 & 4,4-Dimethyl-3-oxacholest-5-en-7-one & 52.28 & 4.47 & 414 & $\mathrm{C}_{28} \mathrm{H}_{46} \mathrm{O}_{2}$ \\
\hline 22 & O-methyl-13-benzoyldehydroalamaridine & 53.09 & 2.18 & 412 & $\mathrm{C}_{26} \mathrm{H}_{24} \mathrm{~N}_{2} \mathrm{O}_{3}$ \\
\hline 23 & Lanosta-8,24-dien-3-ol & $\mathbf{5 3 . 8 2}$ & $4.48 *$ & 426 & $\mathrm{C}_{30} \mathrm{H}_{50} \mathrm{O}$ \\
\hline 24 & 9,19-Cyclolanostane-3,7-diol & 54.04 & 2.44 & 444 & $\mathrm{C}_{30} \mathrm{H}_{52} \mathrm{O}_{2}$ \\
\hline 25 & 17- (1,5-Dimethylhexyl)-10,13-dimethyl-4 vinylhexadecahydrocyclopenta[a]phenanthren-3-ol & 54.58 & 0.75 & 414 & $\mathrm{C}_{29} \mathrm{H}_{50} \mathrm{O}$ \\
\hline 26 & a-Amyrin & 55.20 & $5.39 *$ & 426 & $\mathrm{C}_{30} \mathrm{H}_{50} \mathrm{O}$ \\
\hline 27 & Glycocholic acid methyl ester & 55.70 & 3.15 & 695 & $\mathrm{C}_{36} \mathrm{H}_{69} \mathrm{NO}_{6} \mathrm{Si}_{3}$ \\
\hline 28 & $A^{\prime}$-neogammacer-5-en-3-ol & 56.14 & $14.35^{*}$ & 426 & $\mathrm{C}_{30} \mathrm{H}_{50} \mathrm{O}$ \\
\hline 29 & $\begin{array}{l}\text { 6,9-Dihydroxy-7,8-dichloro-2-methyl-2- } \\
\text { dione }\end{array}$ & 57.25 & 1.13 & 408 & $\mathrm{C}_{20} \mathrm{H}_{18} \mathrm{Cl}_{2} \mathrm{O}_{5}$ \\
\hline \multicolumn{3}{|c|}{ Total identified components } & $87.02 \%$ & & \\
\hline \multicolumn{3}{|c|}{ Total identified hydrocarbons } & $51.1 \%$ & & \\
\hline \multicolumn{3}{|c|}{ Total identified sterols and triterpenes } & $35.92 \%$ & & \\
\hline
\end{tabular}

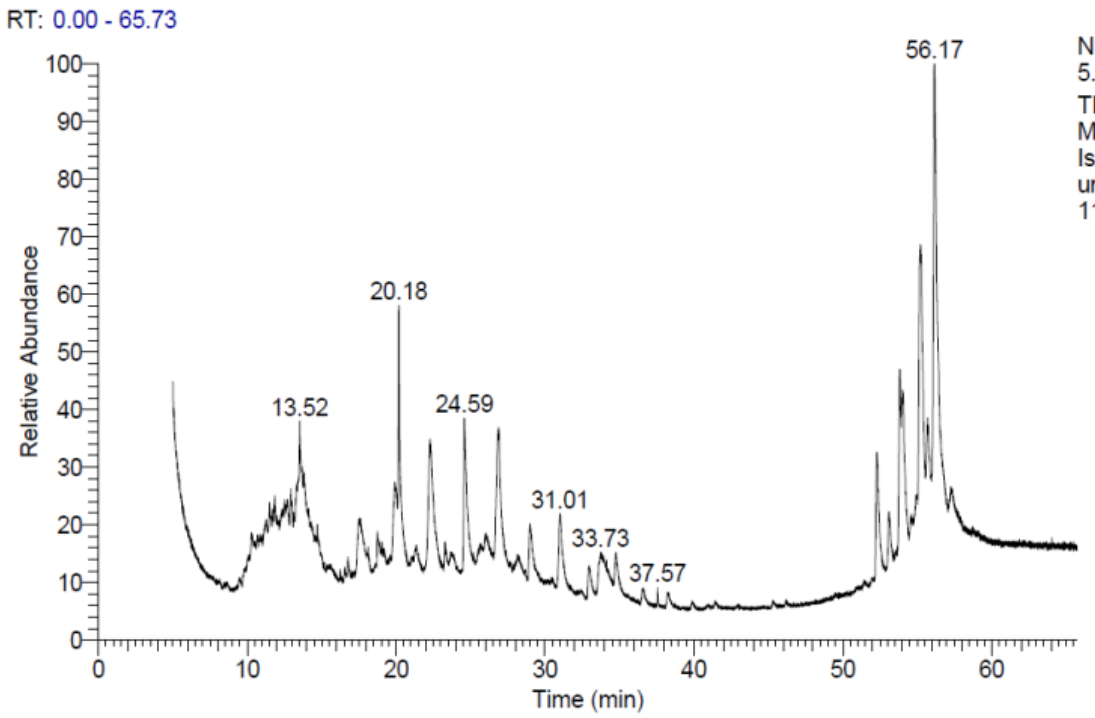

Fig: 2. GC/MS chromatogram of the unsaponifiable matters of Euphorbia grandialata R. aerial parts.

\section{CONCLUSION}

The analysis of the aerial parts of E. grandialata using GC/MS displayed that the saponifiable matter revealed the presence of 14 components. The major saturated and unsaturated fatty acids were methyl isohexadecanoate and 8, 11octadecadienoic acid respectively, while USM showed 29 components; 1-nonanolwas the major hydrocarbon, lanosta-8, 24 dien-3-olwas the major sterol and A'-neogammacer-5-en-3-ol and $\alpha$-amyrin were the major triterpenes. Euphorbia grandialata could be counted as a valuable exporter for natural antioxidants. These antioxidant phytochemicals may be helpful in treatment or prevention of many degenerative diseases such as cancer and other 
human diseases related to oxidative stress. Further work is needed for full characterization of its active principles.

\section{Financial support and sponsorship: Nil.}

Conflict of Interests: There are no conflicts of interest.

\section{REFERENCES}

Abbasi MA, Saleem H, Riaz T, Ajaib M. Determination of Antioxidant Activity and Phytoconstituent Screening of Euphorbia heterophylla Linn. Br J Pharm Res, 2013;3 (2):202-216.

Abu Bakar MF, Mohamed M, Rahmat A, Fry J. Phytochemicals and antioxidant activity of different parts of bambangan (Mangifera pajang) and tarap (Artocarpus odoratissimus). Food Chem, 2009;113 (2):479-483

Agati G, Azzarello E, Pollastri S, Tattini M. Flavonoids as antioxidants in plants: location and functional significance. Plant Sci, 2012;196:67-76.

Al Ashaal HA, Farghaly AA, Abd El Aziz MM AM. Phytochemical investigation and medicinal evaluation of fixed oil of Balanites aegyptiaca fruits (Balantiaceae). J Ethnopharmacol, 2010;127 (2):495-501.

Asha S, Thirunavukkarasu P, Mani VM, Sadiq AM. Antioxidant activity of Euphorbia hirta Linn leaves extracts. European J Med Plants, 2016;14 (1):1-14.

Awaad AS, El-meligy RM, Al-jaber NA, Al-Muteeri HS, Zain ME, Alqasoumi SI, Alafeefy AM, Donia Ael R. Anti-Ulcerative Colitis Activity of Compounds from Euphorbia granuleta Forssk. Phytother Res, 2013;27 (4):1729-1734.

Baba SA and Malik SA. Determination of total phenolic and flavonoid content, antimicrobial and antioxidant activity of a root extract of Arisaema jacquemontii Blume. J. Taibah Univ. Sci, 20159 (4):449454.

Bondarenko OM, Chogovets RK, Litvi nenko VI, Obolentseva GV, Sila VI KT. Euphorbia palustris and Euphorbia stepposa flavonoids and their pharmacological properties. Farm Zh, 1972;26 (6):8-46.

Bravo L. Polyphenols: chemistry, dietary sources, metabolism and nutritional significance. Nutr Rev, 1998;56:317-333.

Dyer RA. Flowering Plants of South Africa. A Magazine Containing Hand-Coloured Figures with Descriptions of the Flowering Plants Indigenous to South Africa. London, Johannesburg and Cape Town; 1937.

Geetha S, Sai Ram M, Mongia SS, Singh V, Ilavazhagan G, Sawhney RC. Evaluation of antioxidant activity of leaf extract of sea buckthorn (Hippophae rhamnoides L.) on chromium (VI) induced oxidative stress in albino rats. J Ethnopharmacol, 2003;87:247-251.

Heirmann A BF. Influence of some traditional medicinal plants of Senegal on prostaglandin biosynthesis. J Ethnopharmacol, 1994;42 (2):6-111

Hussain M, Farooq U, Rashid M, Bakhsh H, Abdul Majeed, Khan IA, Rana SL, Shafeeq-ur-Rahman M, Abdul Aziz. Antimicrobial activity of fresh latex, juice and extract of Euphorbia hirta and Euphorbia thymifolia - an in vitro comparative study Keywords : Int J Pharma Sci, 2014;4 (3):546-553.

Kumar A, Intekhab J. Phytochemical Studies on Euphorbia hypericifolia Abstract: Introduction : Nat Proda Medica, 2013;5 (1):2-5.

Kumar S, Sandhir R OS. Evaluation of antioxidant activity and total phenol in different varieties of Lantana camara leaves. BMC Res Notes, 2014:7:560.

Kupchan SM, Uchida I BA. Antileukemic principles isolated from Euphorbia plants. Science, 1976;191 (2):2-571.

Lahlou FA, Hmimid F, Loutfi M, Bourhim N. Antioxidant Activity and Quantification of Phenolic Compounds of Euphorbia echinus. Int J Pharm Pharm Sci, 2014;6 (2):6-9.
Liu LG, Meng JC, Wu SX Li XY, Zhao XC, Tan RX. New macrocyclic diterpenoids from Euphorbia esula. Planta Med, 2002; 68 (3):8-244.

Majewska M, Skrzycki M, Podsiad MAG, Czeczot H. Evaluation of Antioxidant Potential of Flavonoids : an in Vitro Study. Acta Pol Pharm ñ Drug Res, 2011;68 (4):611-616.

Maoulainine LBM, Jelassi A, Hassen I, Boukhari Aomso. Antioxidant proprieties of methanolic and ethanolic extracts of Euphorbia helioscopia, (L.) Aerial parts. Int Food Res J, 2012;19 (3):1125-1130.

Meng RG, Tian YC, Yang Y, Shi J. Evaluation of DPPH Free Radical Scavenging Activity of Various Extracts of Ligularia fischeri In Vitro: a Case Study of Shaanxi Region. Indian J Pharm Sci, 2016;78 (4):436-442.

Michalak A. Phenolic compounds and their antioxidant activity in plants growing under heavy metal stress. Polish J. of Environ. Stud, 2006; 15:523-530.

Naczk M SF. Phenolics in cereals, fruits and vegetables: occurrence, extraction and analysis. J Pharm Biomed Anal, 2006;41 (5):1523-1542.

Nazemiyeh H, Kazemi EM, Zare K, Jodari M, Nahar L, Sarker SD. Free radical scavengers from the aerial parts of Euphorbia petiolata. J Nat Med, 2010;64 (2):187-190.

Pietta PG. Flavonoids as antioxidants. J Nat Prod, 2000;63:1035-1042

Rahman AH MM and Akter M. Taxonomy and Medicinal Uses of Euphorbiaceae (Spurge) Family of Rajshahi, Bangladesh. Res. Plant Sci, 20131 (3):74-80.

Saleh AMN. Flavonol glycosides of Euphorbia retusa and $E$. sanctae-catharinae. Phytochemistry, 198524 (2):371-372.

Sharma NK, Dey S PR. In vitro antioxidant potential evaluation of Euphorbia hirta L. Pharmacologyonline, 2007;1:91-98.

Shelke P, Derle D, Derle N, Vyawahare J. Preclinical Evaluation and Antiasthmatic Activity of Euphorbia hirta Linn Iinternatiional journal pure appliied biosciience, 2014;2 (2):262-266.

Shimoi K, Masuda S, ShenB, Furugori M, Kinze N. Radioprotective effects of antioxidative plant flavonoids in mice. MutatRes Fund Mol, 1996;350:153-161.

Singh GB, Kaur S, Satti NK, Atal CK MJ. Antiinflammatory activity of the aerial parts of E. peplus. J Ethnopharmacol, 1984;10:55233.

Soobrattee MA, Neergheen VS, Luximon-Ramma A, Aruoma OI, Bahorun T. Phenolics as potential antioxidant therapeutic agents: mechanism and actions. Mutat Res Fundam Mol, 2005;579:200-213.

Vogel AI. Textbook of Practical Organic Chemistry Including Qualitative Organic Analysis. London: English Language Book Society and Longmans Group Ltd; 1975.

Wootton-Beard PC, Moran A RL. Stability of the total antioxidant capacity and total polyphenol content of 23 commercially available vegetable juices before and after in vitro digestion measured by FRAP, DPPH, ABTS and Folin-Ciocalteu methods. Food Res Int, 2011;44 (1):217-224.

Wu Y, Qu W, Geng D, Liang JY, Luo YL. Phenols and flavonoids from the aerial part of Euphorbia hirta. Chin J Nat Med, 2012;10 (1):40-42.

\section{How to cite this article:}

Ismail M, Owis AI, Hetta M, Mohammed R. Total phenolics and flavonoids content, antioxidant activity and GC/MS analyses of Euphorbia grandialata. J App Pharm Sci, 2017; 7 (06): 176-181. 